\title{
Russian science faces economic crisis
}

The Russian part of the ex-Soviet scientific enterprise is facing its economic crisis with fortitude. But these are only early days, and there is worse to come.

\section{Moscow}

A Now-fashionable sport among Russian researchers is the ironical calculation of personal salaries in US dollars. One laboratory director on Thursday last week announced that his salary, now 1,000 rubles a month, is "just $\$ 10$ a month". His purpose was to demonstrate that the present economic situation is self-evidently absurd. But he was out of date. The same week's auction of dollars appears to have set a rate of 210 rubles to the dollar. The director's salary is worth only $\$ 5$ a month. In one sense, of course, it does not matter. The prices of goods may have increased - meat prices have gone from 7 to 70 rubles a kilogram for example - but they are still denominated in rubles. Even so, with the economic reforms only a few weeks old, and with three months of winter (so far mercifully mild) to come, it is mystifying how people hope to plot a strategy for survival. There will be some relief among researchers that the threemonth budget agreed between the Russian government and the Russian Academy of Sciences allows for all salaries to be increased by a factor of 1.9 , but even that will leave many less senior people with salaries of only a few hundred rubles.

The situation creates endless minor humiliations. To buy a bottle of vodka, for example, three conditions must be satisfied: you must have a ration coupon, an empty bottle (to trade for the full one you hope to purchase) and there must be a vodka shop flush with a delivery of full bottles - not a predictable event. So people go to work carrying empty bottles in a plastic bag, just in case good fortune strikes the neighbourhood of their laboratory. Worse, because it is never possible to tell whether there will be vodka or only wine on sale, it makes sense to carry an empty wine bottle as well as one for vodka.

The economic reforms also affect the scientific enterprise more directly. Laboratories that used to enjoy the privilege of an allocation of hard currency have mostly now lost it. The result is that subscriptions to journals have almost everywhere been stopped. (The central library of the Russian Academy of Sciences is said to have abandoned its Nature subscription, for example.) For the same reason, overseas travel has become virtually impossible. It used to be that institute directors could buy air tickets from Aeroflot in rubles overvalued by the old artificial exchange rate. But a ticket to New York is now the equivalent of ten annual salaries. Who will now ask to attend a conference overseas at the cost of ten colleagues' jobs?

Sadly, even the telephone will not be a convenient substitute, except for the laboratories with the foresight and clout to provide themselves with an e-mail link. Last week, it was almost casually announced that the cost of overseas telephone calls will be increased by a factor of 30 , so that a call to a European destination will cost 180 rubles a minute and one to the United States half as much again. It is no wonder that people are musing ironically - as yet, there is no tinge of bitterness in the complaint - that freedom seems to have brought a degree of isolation from the international community even more complete than in the bad old days.

Surprisingly, shortages of laboratory supplies seem less pressing. Molecular biologists, for example, say that there are few difficulties in the supply of radiochemicals from Tomsk (the site of the first Soviet nuclear reactor), while common reagents such as restriction enzymes are also to be had with relative ease. Part of the explanation is that the Russian contribution to the Human Genome Project, one of 14 projects directed centrally by the government, has been supported generously over the past few years, and has chosen to invest heavily in infrastructure. But other more specialized reagents are a much more serious headache: people seem to have become at once skilled and shameless at borrowing scant supplies from colleagues and competitors abroad.

Just a few weeks into economic reform, there is necessarily a sense of unreality about. Often, people have a few dollars saved from the past (but foreign denominated accounts held with the old Soviet Central Bank have been frozen since the bank announced in December that it had run out of reserves; they may be unfrozen again in mid-February, but on terms not yet made public). Now, there is a prospect that people will soon be faced with the loss of jobs. While the Russian Academy of Sciences has, for the time being, resolved that it will not put people out onto the streets, that does not apply to its subsidiary agencies, the army of people working, for example, in its publishing house, Akademie Nauk, which lost 14 million rubles last year.

Different institutes will deal differently with the money problem. At the academy's Institute of Molecular Biology, for example, the plan is that those able to win research grants and contracts from outside will have their salaries substantially increased, perhaps doubled. At some institutes, it is claimed, outside income may well amount to 30 or 40 per cent of total costs. The outside sponsors of research are often other government departments or even industrial enterprises. There may be some nasty shocks ahead if the government's declared intention to balance spending and revenues in the first quarter of the year means that the sponsors are less willing or able to continue their contracts.

At other institutions, bigger upheavals are intended. At Dubna, the cooperative research centre organized around the development of nuclear energy, but now well on the way to becoming a general physical research laboratory, former members of the consortium (including many eastern European governments) have declared their unwillingness to continue, but that gloomy news has been to some extent offset by the discovery that the membership of the old German Democratic Republic (GDR) has now been subsumed in that of Germany as a whole. (The Bonn government undertook to meet the external obligations of the GDR at the time of German unification.) Does that spell a more glamorous future for Dubna than anybody has yet imagined?

Only time will tell. Meanwhile, the government seems to have set about an energetic examination of how the laboratory might be reorganized. The difficulties are huge. Not the least of them is that the town of Dubna, in Upper Volga lakeland country, is a single-purpose company town whose residents consist simply of those required to run the laboratory. Anything like radical change will be a social as well as an economic upheaval.

Meanwhile, the managers at Dubna have taken the most conspicuously enlightened step so far by deciding to recruit a new director for Dubna on the international labour market. A formal advertisement will appear among the classified advertisements in Nature next week. But those who may be interested should send an application and a curriculum vitae to Mr Ivan Bortnik in Moscow on the following numbers: fax (095) 2302460 or e-mailnsenche@ypr01.jinr.dubna.su.The new Russia is plainly determined to rejoin the international community. Will its economic problems allow it to do so successfully?

John Maddox 